\title{
A Review of Driver Genetic Alterations in Thyroid Cancers
}

\author{
Fatemeh Khatami ${ }^{1}$, Seyed Mohammad Tavangar ${ }^{2 *}$ \\ 1. Chronic Diseases Research Center, Endocrinology and Metabolism Population Sciences Insti- \\ tute, Tehran University of Medical Sciences, Tehran, Iran \\ 2. Dept. of Pathology, Dr. Shariati Hospital, Tehran University of Medical Sciences, Tehran, Iran
}

\begin{tabular}{|c|c|}
\hline KEYWORDS & ABSTRACT \\
\hline $\begin{array}{l}\text { Thyroid Cancer; } \\
\text { Proto Oncogene Protein B raf; } \\
\text { MAP kinase signaling system; } \\
\text { Proto-Oncogene } \\
\text { Proteins p21(ras) }\end{array}$ & \multirow{3}{*}{$\begin{array}{l}\text { Thyroid cancer is a frequent endocrine related malignancy with continuous increas- } \\
\text { ing incidence. There has been moving development in understanding its molecular } \\
\text { pathogenesis recently mainly through the explanation of the original role of several } \\
\text { key signaling pathways and related molecular distributors. Central to these mecha- } \\
\text { nisms are the genetic and epigenetic alterations in these pathways, such as mutation } \\
\text { and DNA rearrangements. That does not mean, however, that all the somatic abnor- } \\
\text { malities here in a cancer genome have been involved in development of the cancer and } \\
\text { just driver mutations are concerned in tumor initiation. By way of illustrations, } M A P K \\
\text { pathway which is motivated by } B R A F^{V 600 E} \text { and } R A S \text { and } R E T / P T C \text { rearrangements are } \\
\text { suggesting driver genetic alterations in follicular derived thyroid cancers which are } \\
\text { considered in this review. }\end{array}$} \\
\hline Article Info & \\
\hline $\begin{array}{c}\text { Received } 30 \text { Aug 2017; } \\
\text { Accepted } 14 \text { July 2018; } \\
\text { Published Online 17 July 2018; }\end{array}$ & \\
\hline Corresponding information: & $\begin{array}{l}\text { Seyed Mohammad Tavangar, Dept. of Pathology, Dr. Shariati Hospital, Tehran University of Medical } \\
\text { Sciences, Tehran, Iran. E-mail: Tavangar@ams.ac.ir }\end{array}$ \\
\hline
\end{tabular}

Copyright (C) 2018, IRANIAN JOURNAL OF PATHOLOGY. This is an open-access article distributed under the terms of the Creative Commons Attribution-noncommercial 4.0 International License which permits copy and redistribute the material just in noncommercial usages, provided the original work is properly cited.

\section{Introduction}

Thyroid cancer is the most common endocrine related cancer that its incidence has continuously increased in the last three decades all over the world (1-5). Thyroid carcinomas are heterogeneous groups of neoplasm with typical histopathological features like other tumors (6).

The thyroid gland is composed of two main types of epithelial cells: the follicular cells, which convert iodine into thyroxine, also known as T4, and Triiodothyronine, also known as T3. The thyroid hormones, triiodothyronine (T3) and its prohormone, thyroxine (T4), are tyrosine-based hormones produced by the thyroid gland that are primarily responsible for regui lation of metabolism. Another type of epithelial cells is parafollicular or C-cells, which secrete calcitonin. Primary thyroid cancers initiate from thyroid follicular cells (epithelial tumors) mostly and develop three main pathological types of carcinomas: papillary thyroid carcinoma (PTC), follicular thyroid carcinoma
(FTC) and anaplastic thyroid carcinoma (ATC) contrary to medullary thyroid carcinoma (MTC) that arises from thyroid parafollicular (C) cells (7-9). Because of well differentiation and indolent tumor growth, PTC and FTC are classified as differentiated thyroid cancer (DTC). PTC consists of $85-90 \%$ of all thyroid cancer cases, followed by FTC (5-10\%) and MTC (about 2\%), while ATC accounts for a smaller amount than $2 \%$ of thyroid cancers and usually happens in the aged people (10).

The classic treatment for thyroid cancer is thyroidectomy and adjuvant radioiodine ablation that most patients can be cured, but still surgically inoperative recurrence, refractoriness to radioiodine in DTC, poorly differentiated thyroid carcinoma and ATC are unsolved. In the same way to other solid cancers, thyroid cancer is commenced by genetic alterations and epigenetic changes in driver oncogenes or tumor suppressor genes (11-14). Recent advancement of molecular technologies has brought a new insight to the thyroid tumors diagnosis and prognosis. In this re- 
view, we are mainly focused on the follicular thyroid cell derived cancers genetics in order to shed light on driver genetic alterations and their importance in thyroid tumor genesis.

\section{Molecular genetics of thyroid cancer}

Thyroid cancer comes up as a result of multiple ge- netic and epigenetic alterations in the DNA of cancer cells. There are numerous somatic point mutations and chromosomal rearrangements have been recognized in of different steps follicular cell-derived thyroid cancer (Figure 1) $(15,16)$ whose are mainly be) longing to the $M A P K$ signaling pathway and RET/ PTC rearrangements (17).

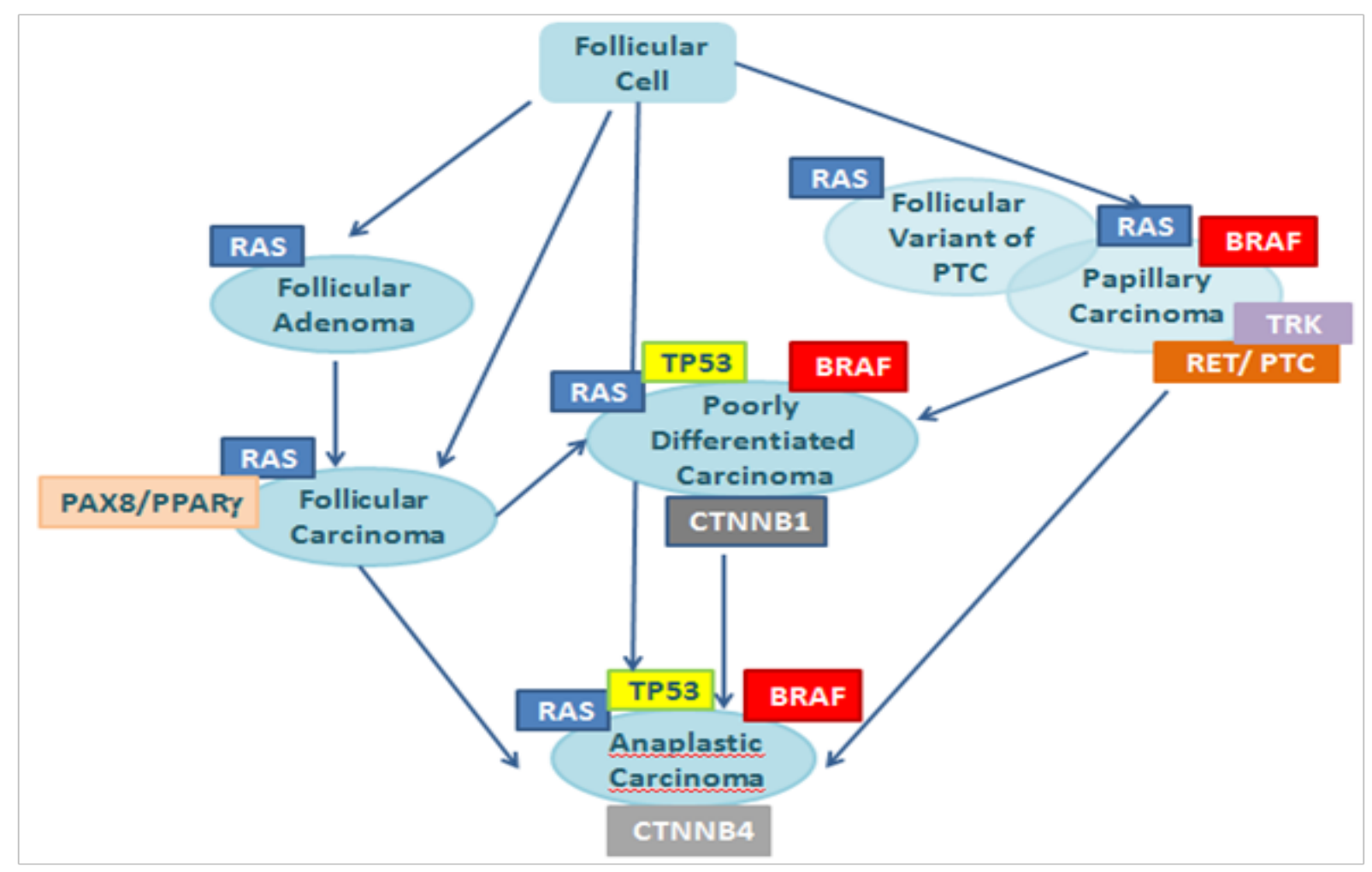

Figure 1. Stepwise dedifferentiation of follicular cell-derived thyroid cancer.

It should be kept in mind that not all the somatic abnormalities of a cancer genome have been involved in initiation of the cancer because some are the consequences of carcinogenesis, so the terms 'driver> and 'passenger> mutation have been made up. A driver mutation is by the way oncogenesis implication which is cancer stem cells and has been positively selected in the microenvironment of the tissue in which the cancer begins and is not needed for maintenance of the final cancer (although it often is) $(18,19)$.

A passenger mutation has not been chosen, has not given clonally increase and has therefore not contribute to cancer development. For the reason that somatic mutations without functional consequences often happen during cell division, passenger mutations are initiated within cancer genomes (20). One of the problematic issues is discriminating driver from passenger mutations. Whole-genome sequencing, however, incorporating analysis of more than 20,000 protein-coding genes and unknown numbers of functional elements in intronic and intergenic DNA, presents a greater challenge. Investigation of the biological consequences of putative driver mutations will often consolidate the evidence implicating them in oncogenesis and will provide insight into the subverted biological processes by which they contribute to cancer development. Thyroid cancer is a genetically simple disease with a relatively low num- 
ber of mutations in each tumor. Driver mutations and gene fusions are identified in most of thyroid cancers suggesting that two main cell signaling pathways are MAPK and PI3K-AKT involved in the development of thyroid tumors $(17,21)$. The $M A P K / E R K$ pathway, also known as the Ras-Raf-MEK-ERK pathway, is a transporter of a signal from a receptor on the cell surface to the nucleus (DNA) (Figure 2). After binding a signaling molecule to its target receptor on the cell surface, this signaling pathway initiates and when the
DNA in the nucleus expresses a protein in order to make some changes in the cell, it will be terminated (22). This pathway have lots of proteins, including $M A P K$ (mitogen-activated protein kinases, originally called $E R K$, extracellular signal-regulated kinases) and is connected with the cell proliferation, differentiation, migration, senescence and apoptosis Components of the $M A P K / E R K$ pathway were discovered when they were found in cancer cells $(6,22-24)$.

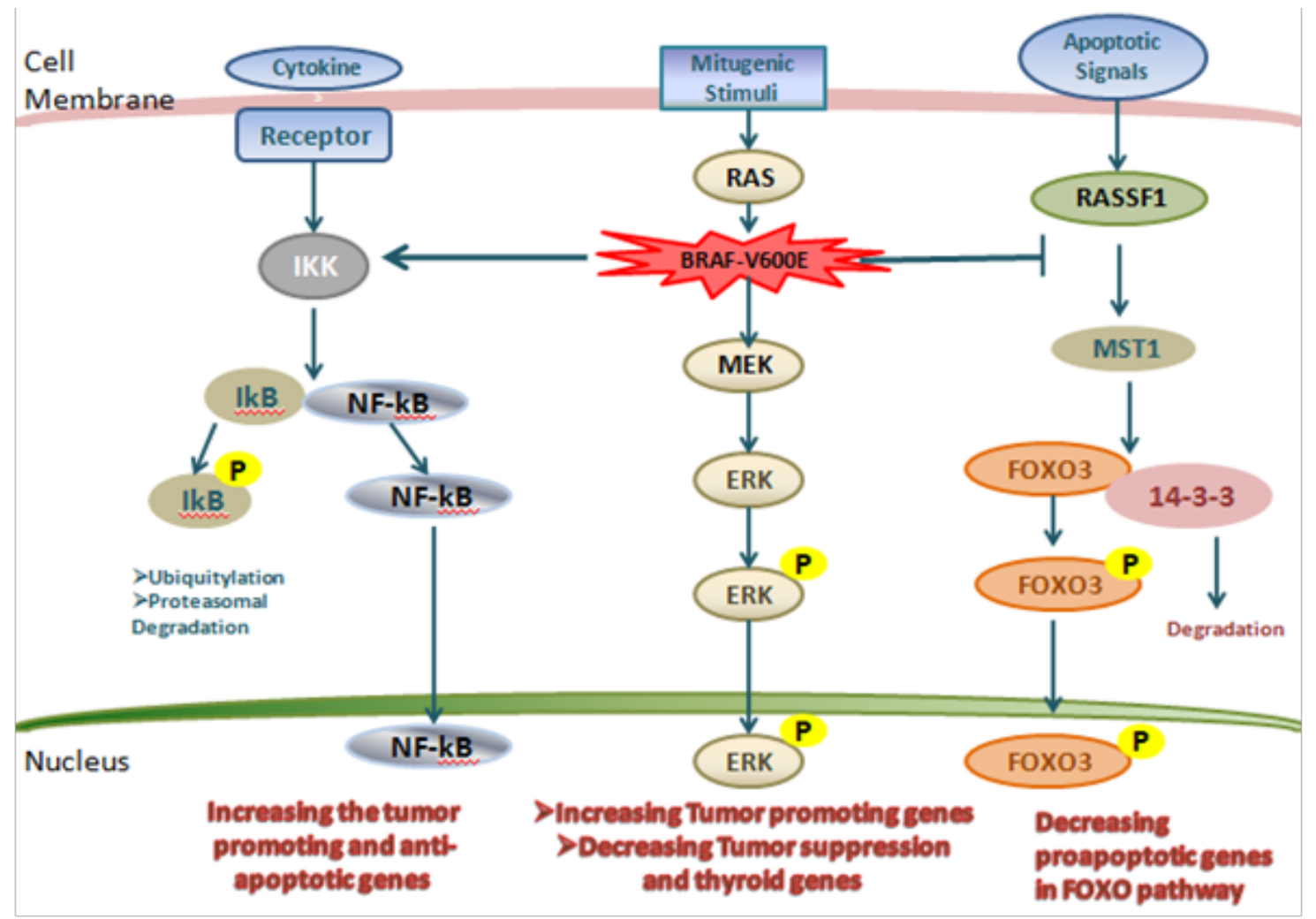

Figure 2. The MAPK and related pathways in thyroid cancer.

Nuclear factor- $\kappa \mathrm{B}(\mathrm{NF}-\kappa \mathrm{B})$ pathway that is leading to activation of the inhibitor of $\kappa \mathrm{B}(\mathrm{I} \kappa \mathrm{B})$ kinase (IKK), resulting in the

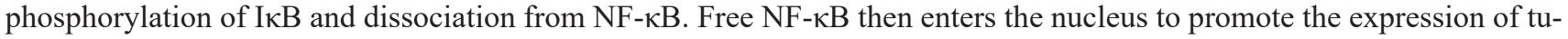
mor-promoting genes. On the right side of the figure is the RASSF1-mammalian STE20-like protein kinase 1 (MST1)-fork head box O3 (FOXO3) pathway and activated MST1 then phosphorylates FOXO3 on Ser207. Phosphorylated FOXO3 enters the nucleus to promote the expression of pro-apoptotic genes in the FOXO pathway. In the middle of figure is a unique and powerful mechanism of thyroid tumor genesis driven by BRAF-V600E. DAPK1, death-associated protein kinase 1; HIF1A, hypoxia-inducible factor $1 \alpha$; MMP, matrix metalloproteinase; NIS, sodium-iodide symporter; TGFB1, transforming growth factor $\beta 1$; TIMP3, tissue inhibitor of metallo proteinases 3; TPO, thyroid peroxidase; TSHR, thyroid-stimulating hormone receptor; TSP1, thrombospondin 1; UPA, urokinase plasminogen activator; UPAR, urokinase plasminogen activator receptor; VEGFA, vascular endothelial growth factor A (25).

In early thyroid cancer, $M A P K$ pathway is motivated by mutations in $B R A F$ and $R A S$ or by $R E T / P T C$ rearrangements. A key driver mutation upsetting $M A P K$ pathway is the point mutation of $B R A F$, which make the expression of $B R A F^{V 600 E}$ mutant protein resulting in constitutive activation of the serine/threonine kinas
(26-31). In fact, amino acid substitution at position 600 in $B R A F$, from a Valine (V) to a glutamic acid (E) is the result of $\mathrm{V} 600 \mathrm{E}$ mutation. This mutation oct curs within the activation segment of the kinase dos main (Figure 3). BRAF mutations also are frequently found in tumors with no driver mutations in $N R A S$, 
$K I T$, and other genes. BRAF ${ }^{V 600 E}$ mutation is found in about $45 \%$ of PTCs $(32,33)$. However, some human PTC tumors have been found to show intra-tumors heterogeneity in the $B R A F$ genotype - with a minority of cells have $B R A F^{V 600 E}$ while the majority contain wild-type BRAF (34).

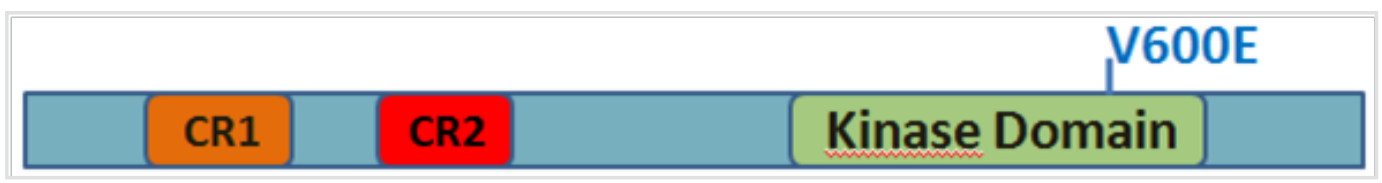

Figure 3. Schematic of $B R A F$ VGOOE mutation. Functional domains of $B R A F$ are depicted. CR1: conserved regions 1. CR2: conserved region 2.

After $B R A F$ mutations in thyroid cancer $R A S$ mutations are the most important driver genetic alteration $(35,36) . R A S$ is in bound with GTP and when intrinsic GTPase of RAS hydrolyses GTP and converts $R A S$ into an inactive GDP-bound state the RAS signaling terminated (Figure 4) (37). There are three isoforms of RAS: HRAS, KRAS and NRAS, and NRAS is predominantly mutated in thyroid tumors, mostly involving codons 12 and 61(30,38). The $R A S$ mutations in follicular thyroid adenoma (FTA), a supposed premalignant lesion, suggests that activated $R A S$ may have a role in early follicular thyroid cell tumor genesis and higher aggressive tumor behaviors $(38,39)$. The expression of mutant $H R A S$ was induced in resulted in differentiated colonies (39-41). Moreover, in the thyroid gland of transgenic mouse studies with conditional physiological expression of a KRAS had no transformation, but simultaneous KRAS mutant expression and PTEN deletion induced a rapid occurrence of aggressive FTC (42-44).

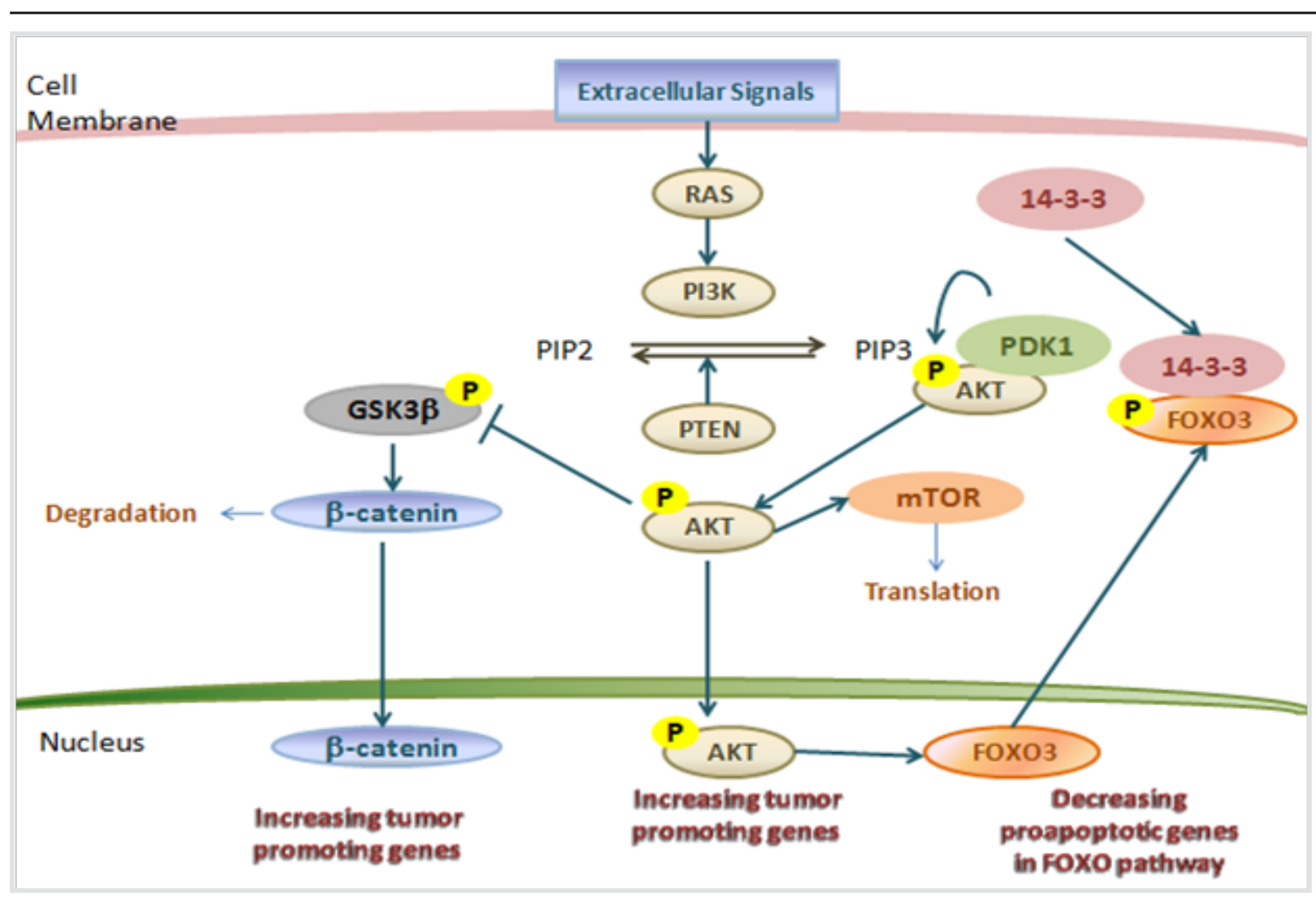

Figure 4. The PI3K-AKT and related pathways in thyroid cancer (37). 
Another main driver genetic alteration in thyroid cancer is the rearranged during transfusion (RET) proto-oncogene. $R E T$ is (rearranged during transfection), is localized on chromosome 10 (10q11.2) and have 21 exons (45). The natural alternative splicing of the RET gene consequences in the making of three differi ent isoforms of the protein RET; RET51, RET43, and RET9 which have 51, 43 and 9 amino acids in their C-terminal tail respectively (46) . Each protein is dit vided into three domains: an N-terminal extracellular domain with four cadherin-like repeats and a cysteinerich region, a hydrophobic trans membrane domain and a cytoplasmic tyrosine kinase domain, which is split by an insertion of 27 amino acids (47). As a res sult of its capability to transform NIH/3T3 cells by DNA rearrangement, the RET proto-oncogene was first recognized in 1985 (48). The proteins that RET encodes is a cellular tyrosine kinase transmembrane receptor that is separated into the three main domains: an N-terminal extracellular domain containing four cadherin-like regions; a cysteine-rich region with a transmembrane domain; and a cytoplasmic domain with tyrosine kinase activity $(47,49-51)$. Four diverse ligands have been described: Glial Derived Neurotrophic $(G D N)$ factors, Neurturin $(N R T N)$, Artimin $(A R T N)$, and Persepin $(P S P N)$, respectively $(47,52$, $53)$. DNA rearrangements are a result of homologous recombination, gene conversion, and illegitimate recombination. During homologous recombination in a cell containing more than one copy of a given chromosome one copy can combine with corresponding segments of the other. This kind of recombination is ultimately dependent upon the DNA sequence homology between the two copies. Several types of RET/ $P T C$ rearrangements have been reported (Table 1) $(54,55)$. The presence of RET/PTC rearrangement in microcarcinoma powerfully support the hypothesis of a driving role of this oncogene in the tumor transformation (56).

Table 1. Different types of RET/PTC rearrangements in thyroid tumors according to Nikiforov YE (57)

\begin{tabular}{ccc}
\hline Oncogene & Donor gene & Chromosomal location \\
\hline RET/PTC1 & CCD6(formerly H4) & $10 \mathrm{q} 21$ \\
\hline RET/PTC2 & PRKAR1A & $17 \mathrm{q} 23$ \\
\hline RET/PTC3 & NCO4 (formerly Ele 1) & $10 \mathrm{q} 11.2$ \\
\hline RET/PTC4 & NCO4 (formerly Ele1) & $10 \mathrm{q} 11.2$ \\
\hline RET/PTC5 & Golgas & $14 \mathrm{q}$ \\
RET/PTC6 & TRIM24 & $7 \mathrm{q} 32-34$ \\
RET/PTC7 & TRIM33 & $1 \mathrm{p} 13$ \\
\hline RET/PTC8 & KTN1 & $14 \mathrm{q} 22.1$ \\
\hline RET/PTC9 & RFG9 & $18 \mathrm{q} 21-22$ \\
\hline ELKS-RET & ELKS & $12 \mathrm{p} 13.3$ \\
\hline PCM1-RET & PCM1 & $8 \mathrm{p} 21-22$ \\
\hline RFP-RET & TRIM27 & $6 \mathrm{p} 21$ \\
\hline HOOK3-RET & HOOK3 & $8 \mathrm{p} 11.21$ \\
\hline
\end{tabular}

The described RET/PTC prevalence in thyroid tumors varies greatly in different studies (58-65). However, this difference can be the consequence of Tumor heterogeneity, ethnical and geographic variations, and dissimilar sensitivities of detection methods (66-68). $R E T / P T C$ rearrangements are more often in thyroid cancers after radiation exposure (50-80\%) (69-72). The biological mechanisms of radiation carcinogenesis related to RET/PTC rearrangements have been studied several times. It has been shown that damage to cellular DNA is responsible for mutagenesis and carcinogenesis and those double-strand breaks 
is the most important event for the direct generation of gene translocations and rearrangements $(21,73$ 77). Thanks to the recent advanced next generation sequencing, and whole genome sequencing the number of candidate genetic changes in thyroid cancer has increased (78). But it is really important to discriminate between driver and passenger ones. Other genetic changes that are considered as passenger mutations include: PI3K (phosphatidylinositol-3 kinase), $\beta$-catenin (CTNNB 1), TP53, isocitrate dehydrogenase $1(I D H 1)$, anaplastic lymphoma kinase $(A L K)$ and epidermal growth factor receptor (EGFR) (79-89). The preferential occurrences of these mutations in PDTC and ATC, which are the most aggressive thyroid cancers, indicate to the fact that they may have a role in the progression and aggressiveness of thyroid cancer.

\section{Conclusions}

While diverse oncogenes have been brought into being involved in thyroid tumor genesis, $B R A F$ and RAS mutations, and RET/PTC rearrangements are the most frequently involved as a driver changes. Notwithstanding all these observations, there are not still strong supporting data showing a classic prognostic role for $B R A F$ and $R A S$ mutations, and RET/ $P T C$ rearrangements. But it is clear that RET/PTC rearrangements are connected to radiation exposure and are more recurrent in patients with radio induced PTC.

\section{Acknowledgment}

Authors acknowledge their gratitude to Endocrinology and Metabolism Population Sciences Institute, Tehran University of Medical Sciences. This article was a part of a superior project which was granted by the National Institute for Medical Research Development (NIMAD, Grant number: 957222).

\section{Conflict of Interest}

The authors declare that there was no conflict of interest.

\section{References}

1. Curado M-P, Edwards B, Shin HR, Storm H, Ferlay J, Heanue M, et al. Cancer incidence in five continents, Vol 4. Lyon: IARC Press, International Agency for Research on Cancer; 2007.

2. Pellegriti G, Frasca F, Regalbuto C, Squatrito $\mathrm{S}$, Vigneri R. Worldwide increasing incidence of thyroid cancer: update on epidemiology and risk factors. J Cancer Epidemiol. 2013;2013. http://dx.doi.org/10.1155/2013/965212

3. Larijani B, Shirzad M, Mohagheghi M, Haghpanah V, Mosavi-Jarrahi A, Tavangar S, et al. Epidemiologic analysis of the Tehran cancer institute data system registry (TCIDSR). Asian Pac J Cancer Prev. 2004;5(1):36-9. PMID: 15075002

4. Haghpanah V, Soliemanpour B, Heshmat R, Mosavi-Jarrahi A, Tavangar S, Malekzadeh R, et al. Endocrine cancer in Iran: based on cancer registry system. Indian $\mathrm{J}$ Cancer. 2006;43(2):80-5. https://doi.org/10.4103/0019509X.25889_PMID: $\underline{16790945}$

5. Larijani B, Mohagheghi MA, Bastanhagh MH, Mosavi-Jarrahi AR, Haghpanah V, Tavangar SM, et al. Primary thyroid malignancies in Tehran, Iran. Med Princ Pract. 2005;14(6):396-400.https://doi. org/10.1159/000088112P MID: 16220012

6. Nasseri-Moghaddam S, Malekzadeh R, Sotoudeh M, Tavangar M, Azimi K, Sohrabpour AA, et al. Lower esophagus in dyspeptic Iranian patients: a prospective study. J Gastroenterol Hepatol. 2003;18(3):315-21. https://doi.org/10.1046/ j.1440-1746.2003.02969.x PMID: 12603533

7. DeLellis RA. Pathology and genetics of tumours of endocrine organs. Lyon: IARC; 2004.

8. Nikiforov YE, Biddinger PW, Thompson LD. Diagnostic pathology and molecular genetics of the thyroid: a comprehensive guide for practicing thyroid pathology. Philadelphia: Lippincott Williams \& Wilkins; 2012.

9. Sanii S, Saffar H, Tabriz HM, Qorbani M, Haghpanah V, Tavangar SM. Expression of matrix metalloproteinase-2, but not caspase-3, facilitates distinction between benign and malignant thyroid follicular neoplasms. Asian Pac J Cancer Prev. 2012;13(5):2175- 
8. https://doi.org/10.7314/APJCP.2012.13.5.2175 PMID: $\underline{22901190}$

10. Larijani B, Shirzad M, Mohagheghi M, Haghpanah V, Jarahi AM, Tavangar S, et al. Epidemiologic feature of thyroid cancer based on cancer registry data system. Iran J Public Health. 2005;34(4):1-7. http://ijph.tums.ac.ir/index.php/ ijph/article/view/1836

11. Rashid S. Hallmarks of Cancer Cell. Cancer and Chemoprevention: An Overview. New York: Springer; 2017. p. 3-13. https://doi. org/10.1007/978-981-10-2579-2_2

12. Hanahan D, Weinberg RA. The hallmarks of cancer. cell. 2000;100(1):57-70.https://doi. org/10.1016/S0092-8674(00)81683-9

13. Amoli MM, Yazdani N, Amiri P, Sayahzadeh F, Haghpanah V, Tavangar SM, et al. HLADR association in papillary thyroid carcinoma. Dis Markers. 2010;28(1):49-53. https://doi. org/10.1155/2010/130276 PMID:20164547

14. Khatami F, Tavangar SM. Current Diagnostic Status of Pheochromocytomaand Future Perspective: A Mini Review. Iran J Pathol. 2017;12(3):313-22. PMID:29531562 PMCID:PMC5835385

15. Rossing M. Classification of follicular cell-derived thyroid cancer by global RNA profiling. J Mol Endocrinol. 2013;50(2):R39-51. https://doi. org/10.1530/JME-12-0170 PMID:23355745

16. Katoh H, Yamashita K, Enomoto T, Watanabe $M$. Classification and general considerations of thyroid cancer. Ann Clin Pathol. 2015;3(1):1045-54. https://www.jscimedcentral.com/Pathology/pathology-3-1045.pdf

17. Nikiforov YE. Molecular analysis of thyroid tumors. Mod Pathol. 2011;24(S2):S34-43. https://doi.org/10.1038/modpathol.2010.167 PMID:21455199

18. Pon JR, Marra MA. Driver and passenger mutations in cancer. Annu Rev Pathol. 2015;10:25-50. https://doi.org/10.1146/annurev-pathol-012414-040312 PMID:25340638

19. Bozic I, Antal T, Ohtsuki H, Carter H, Kim D, Chen S, Karchin R, Kinzler KW, Vogelstein B, Nowak MA. Accumulation of driver and passenger mutations during tumor progression.
Proc Natl Acad Sci U S A. 2010;107(43):18545-

50. https://doi.org/10.1073/pnas.1010978107 PMID:20876136

20. Matsumoto T, Shimizu T, Takai A, Marusawa H. Exploring the mechanisms of gastrointestinal cancer development using deep sequencing analysis. Cancers. 2015;7(2):1037-51. PMID:26083936

21. Kajbafzadeh A-M, Payabvash S, Salmasi AH, Monajemzadeh M, Tavangar SM. Smooth muscle cell apoptosis and defective neural development in congenital ureteropelvic junction obstruction. J Urol. 2006;176(2):718-23. https://doi. org/10.1016/j.juro.2006.03.041 PMID: 16813927

22. Sun Y, Liu W-Z, Liu T, Feng X, Yang N, Zhou $\mathrm{H}-\mathrm{F}$. Signaling pathway of MAPK/ERK in cell proliferation, differentiation, migration, senescence and apoptosis. J Recept Signal Transduct Res. 2015;35(6):600-4. https://doi.org/10.3109/10 799893.2015.1030412 PMID:26096166

23. Haddadi-Nezhad S, Larijani B, Tavangar SM, Nouraei SM. Comparison of fine-needle-nonaspiration with fine-needle-aspiration technique in the cytologic studies of thyroid nodules. Endocr Pathol. 2003;14(4):369-73. https:// doi.org/10.1385/EP:14:4:369 PMID:14739493

24. Tavangar S, Monajemzadeh M, Larijani B, Haghpanah V. Immunohistochemical study of oestrogen receptors in 351 human thyroid glands. Singapore Med J. 2007;48(8):744-7. PMID: 17657383

25. Orton RJ, Sturm OE, Vyshemirsky V, Calder M, Gilbert DR, Kolch W. Computational modelling of the receptor-tyrosine-kinase-activated MAPK pathway. Biochem J. 2005;392(2):249-61.https://doi.org/10.1042/ BJ20050908_PMID: $\underline{16293107}$

26. Xing M. Molecular pathogenesis and mechanisms of thyroid cancer. Nat Rev Cancer. 2013;13(3):184. PMID:23429735

27. Cohen $\mathrm{Y}$, Xing M, Mambo E, Guo Z, Wu $\mathrm{G}$, Trink B, et al. BRAF mutation in papillary thyroid carcinoma. J Natl Cancer Inst. 2003;95(8):625-7. https://doi.org/10.1093/ jnci/95.8.625 PMID: 12697856

28. Soares P, Trovisco V, Rocha AS, Lima J, Cas- 
tro $\mathrm{P}$, Preto A, et al. BRAF mutations and RET/PTC rearrangements are alternative events in the etiopathogenesis of PTC. Oncogene. 2003;22(29):4578. https://doi.org/10.1038/ sj.onc.1206706 PMID: 12881714

Namba H, Nakashima M, Hayashi T, Hayashida N, Maeda S, Rogounovitch TI, et al. Clinical implication of hot spot BRAF mutation, V599E, in papillary thyroid cancers. J Clin Endocrinol Metab. 2003;88(9):4393-7. https://doi. org/10.1210/jc.2003-030305 PMID:12970315

30. Kimura ET, Nikiforova MN, Zhu Z, Knauf JA, Nikiforov YE, Fagin JA. High prevalence of BRAF mutations in thyroid cancer. Cancer Res. 2003;63(7):1454-7. PMID:12670889

31. Khatami F, Larijani B, Tavangar S. Circulating Tumor BRAF Mutation and Personalized Thyroid Cancer Treatment. Asian Pac J Cancer Prev. 2017;18(2):293-4. https://doi.org/10.22034/ APJCP.2017.18.2.293 PMID:28345323

32. Yarchoan M, LiVolsi VA, Brose MS. BRAF Mutation and Thyroid Cancer Recurrence. J Clin Oncol. 2015;33(1):7-8. https://doi.org/10.1200/ JCO.2014.59.3657

33. Larijani B, Khorgami Z, Tavangar S, Haghpanah V, Mehdipour P. Prevalence of BRAFV600E mutation in Iranian patients with papillary thyroid carcinoma: a single-center study. J Appl Sci. 2009;9(19):3593-7. https://doi.org/10.3923/ jas.2009.3593.3597

34. Xing M. BRAF mutation in thyroid cancer. Endocr Relat Cancer. 2005;12(2):245-62. https:// doi.org/10.1677/erc.1.0978 PMID:15947100

35. Howell GM, Hodak SP, Yip L. RAS mutations in thyroid cancer. Oncologist. 2013;18(8):926-32. https://doi.org/10.1634/theoncologist.2013-0072 PMID:23873720 PMCID:PMC3755930

36. Mohammadi-asl J, Larijani B, Khorgami Z, Tavangar SM, Haghpanah V, Kheirollahi M, et al. Qualitative and quantitative promoter hypermethylation patterns of the P16, TSHR, RASSF1A and RAR $\beta 2$ genes in papillary thyroid carcinoma. Med Oncol. 2011;28(4):1123-

8. https://doi.org/10.1007/s12032-010-9587-z PMID:20535589

37. Xing M. Molecular pathogenesis and mech- anisms of thyroid cancer. Nat Rev Cancer. 2013;13(3):184-99. https://doi. org/10.1038/nrc3431 PMID:23429735 PMCID:PMC3791171

38. Xing M. Clinical utility of RAS mutations in thyroid cancer: a blurred picture now emerging clearer. BMC Med. 2016;14(1):12. https://doi. org/10.1186/s12916-016-0559-9 PMID:26817707

39. Puzziello A, Guerra A, Murino A, Izzo G, Carrano $\mathrm{M}$, Angrisani E, et al. Benign thyroid nodules with RAS mutation grow faster. Clin Endocrinol (Oxf). 2016;84(5):736-40. https://doi. org/10.1111/cen.12875 PMID:26260959

40. Gire V, Wynford-Thomas D. RAS oncogene activation induces proliferation in normal human thyroid epithelial cells without loss of differentiation. Oncogene. 2000;19(6):737. https://doi. org/10.1038/sj.onc.1203399 PMID:10698491

41. Bond J, Wyllie F, Rowson J, Radulescu A, Wynford-Thomas D. In vitro reconstruction of tumour initiation in a human epithelium. Oncogene. 1994;9(1):281-90. PMID: $\underline{8302590}$

42. Miller KA, Yeager N, Baker K, Liao X-H, Refetoff S, Di Cristofano A. Oncogenic Kras requires simultaneous PI3K signaling to induce ERK activation and transform thyroid epithelial cells in vivo. Cancer Res. 2009;69(8):3689-94. https://doi.org/10.1158/0008-5472.CAN-09-0024 PMID:19351816 PMCID:PMC2669852

43. Sarmadi S, Izadi-Mood N, Sotoudeh K, Tavangar SM. Altered PTEN expression; a diagnostic marker for differentiating normal, hyperplastic and neoplastic endometrium. Diagn Pathol. 2009;4(1):41. https://doi.org/10.1186/1746-15964-41 PMID:19930726

44. Razavi SA, Modarressi MH, Yaghmaei P, Tavangar SM, Hedayati M. Circulating levels of PTEN and KLLN in papillary thyroid carcinoma: can they be considered as novel diagnostic biomarkers? Endocrine. 2017:57(3):42835. https://doi.org/10.1007/s12020-017-1368-4 PMID:28755140

45. Ceccherini I, Bocciardi R, Luo Y, Pasini B, Hofstra R, Takahashi M, et al. Exon Structure and Flanking Intronic Sequences of the Human RET Proto-oncogene. Biochem Biophys Res 
Commun. 1993;196(3):1288-95. https://doi.



46. Myers SM, Eng C, Ponder BA, Mulligan LM. Characterization of RET proto-oncogene 3 ' splicing variants and polyadenylation sites: a novel C-terminus for RET. Oncogene. 1995;11(10):2039-45. PMID:7478523

47. Arighi E, Borrello MG, Sariola H. RET tyrosine kinase signaling in development and cancer. Cytokine Growth Factor Rev. 2005;16(4):441-

67. https://doi.org/10.1016/j.cytogfr.2005.05.010 PMID:15982921

48. Takahashi M, Ritz J, Cooper GM. Activation of a novel human transforming gene, ret, by DNA rearrangement. Cell. 1985;42(2):581-8.https:// doi.org/10.1016/0092-8674(85)90115-1

49. Anders J, Kjær S, Ibá-ez CF. Molecular modeling of the extracellular domain of the RET receptor tyrosine kinase reveals multiple cadherin-like domains and a calcium-binding site. J Biol Chem. 2001;276(38):35808-17. https://doi. org/10.1074/jbc.M104968200 PMID: 11445581

50. Ibá-ez CF. Structure and physiology of the RET receptor tyrosine kinase. Cold Spring Harb Perspect Biol. 2013;5(2):a009134. https://doi. org/10.1101/cshperspect.a009134 PMID:23378586 PMCID:PMC3552510

51. Goodman KM, Kjær S, Beuron F, Knowles PP, Nawrotek A, Burns EM, et al. RET recognition of GDNF-GFR $\alpha 1$ ligand by a composite binding site promotes membrane-proximal self-association. Cell Rep. 2014;8(6):1894-904. https://doi. org/10.1016/j.celrep.2014.08.040 PMID:25242331

52. Santoro M, Rosati R, Grieco M, Berlingieri M, D'amato G, De Franciscis V, et al. The ret proto-oncogene is consistently expressed in human pheochromocytomas and thyroid medullary carcinomas. Oncogene. 1990;5(10):15958. PMID: 1701232

53. Menicali E, Moretti S, Voce P, Romagnoli S, Avenia N, Puxeddu E. Intracellular Signal Transduction and Modification of the Tumor Microenvironment Induced by RET/PTCs in Papillary Thyroid Carcinoma. Front Endocrinol (Lausanne). 2012;3:67. https://doi. org/10.3389/fendo.2012.00067 PMID: $\underline{22661970}$

\section{PMCID:PMC3357465}

54. Greco A, Borrello M, Miranda C, Degl'Innocenti D, Pierotti M. Molecular pathology of differentiated thyroid cancer. Q J Nucl Med Mol Imaging. 2009;53(5):440-53. PMID:19910897

55. Ciampi R, Giordano TJ, Wikenheiser-Brokamp K, Koenig RJ, Nikiforov YE. HOOK3-RET: a novel type of RET/PTC rearrangement in papillary thyroid carcinoma. Endocr Relat Cancer. 2007;14(2):445-52. https://doi.org/10.1677/ERC07-0039 PMID: 17639057

56. Viglietto G, Chiappetta G, Martinez-Tello FJ, Fukunaga FH, Tallini G, Rigopoulou D, et al. RET/PTC oncogene activation is an early event in thyroid carcinogenesis. Oncogene. 1995;11(6):1207-10. PMID:

57. Nikiforov YE. RET/PTC rearrangement in thyroid tumors. Endocr Pathol. 2002;13(1):3-16. PMID: 12114746

58. Zou M, Shi Y, Farid NR. Low rate of ret protooncogene activation (PTC/retTPC) in papillary thyroid carcinomas from saudi arabia. Cancer. 1994;73(1):176-80. PMID:8275421

59. Tallini G, Asa SL, Fuller GN. RET oncogene activation in papillary thyroid carcinoma. Adv Anat Pathol. 2001;8(6):345-54. https:// doi.org/10.1097/00125480-200111000-00005 PMID: 11707626

60. Chua EL, Wu WM, Tran KT, McCarthy SW, Lauer CS, Dubourdieu D, et al. Prevalence and distribution of ret/ptc 1,2 , and 3 in papillary thyroid carcinoma in New Caledonia and Australia. J Clin Endocrinol Metab. 2000;85(8):2733-9. $\quad$ https://doi.org/10.1210/ jc.85.8.2733 PMID: 10946873

61. Fenton CL, Lukes Y, Nicholson D, Dinauer CA, Francis GL, Tuttle RM. The ret/PTC mutations are common in sporadic papillary thyroid carcinoma of children and young adults. J Clin Endocrinol Metab. 2000;85(3):1170-5. https://doi. org/10.1210/jc.85.3.1170 PMID: 10720057

62. Sheils O, O'Leary J, Uhlmann V, Lüttich K, Sweeney E. ret/PTC-1 activation in Hashimoto thyroiditis. Int J Surg Pathol. 2000;8(3):1859. https://doi.org/10.1177/106689690000800305 PMID: 11493988 
63. Puxeddu E, Moretti S, Giannico A, Martinelli M, Marino C, Avenia N, et al. Ret/PTC activation does not influence clinical and pathological features of adult papillary thyroid carcinomas. Eur J Endocrinol. 2003;148(5):505-13. https:// doi.org/10.1530/eje.0.1480505 PMID: 12720532

Rhoden KJ, Unger K, Salvatore G, Yilmaz Y, Vovk V, Chiappetta G, et al. RET/papillary thyroid cancer rearrangement in nonneoplastic thyrocytes: follicular cells of Hashimoto's thyroiditis share low-level recombination events with a subset of papillary carcinoma. J Clin Endocrinol Metab. 2006;91(6):2414-23. https://doi. org/10.1210/jc.2006-0240 PMID: 16595592

Rhoden KJ, Johnson C, Brandao G, Howe JG, Smith BR, Tallini G. Real-time quantitative RTPCR identifies distinct c-RET, RET/PTC1 and RET/PTC3 expression patterns in papillary thyroid carcinoma. Lab Invest. 2004;84(12):1557.

https://doi.org/10.1038/labinvest.3700198 PMID: 15502856

Zhu Z, Ciampi R, Nikiforova MN, Gandhi $M$, Nikiforov YE. Prevalence of RET/PTC rearrangements in thyroid papillary carcinomas: effects of the detection methods and genetic heterogeneity. J Clin Endocrinol Metab. 2006;91(9):3603-10. https://doi.org/10.1210/ jc.2006-1006 PMID: $\underline{16772343}$

67. Marotta V, Guerra A, Sapio MR, Vitale M. RET/PTC rearrangement in benign and malignant thyroid diseases: a clinical standpoint. Eur J Endocrinol. 2011;165(4):499-507. https://doi. org/10.1530/EJE-11-0499 PMID:21750045

68. Unger K, Zitzelsberger H, Salvatore G, Santoro $\mathrm{M}$, Bogdanova $\mathrm{T}$, Braselmann $\mathrm{H}$, et al. Heterogeneity in the distribution of RET/PTC rearrangements within individual post-Chernobyl papillary thyroid carcinomas. J Clin Endocrinol Metab. 2004;89(9):4272-9. https://doi. org/10.1210/jc.2003-031870 PMID:15356021

69. Hieber L, Huber R, Bauer V, Schäffner Q, Braselmann H, Thomas G, et al. Chromosomal rearrangements in post-Chernobyl papillary thyroid carcinomas: evaluation by spectral karyotyping and automated interphase FISH. J Biomed Biotechnol. 2011;2011:693691. http:// dx.doi.org/10.1155/2011/693691 PMID:21436994
70. Hamatani K, Eguchi H, Ito R, Mukai M, Takahashi K, Taga M, et al. RET/PTC rearrangements preferentially occurred in papillary thyroid cancer among atomic bomb survivors exposed to high radiation dose. Cancer Res. 2008;68(17):7176-82.https://doi. org/10.1158/0008-5472.CAN-08-0293

71. Di Cristofaro J, Vasko V, Savchenko V, Cherenko S, Larin A, Ringel M, et al. ret/PTC1 and ret/PTC3 in thyroid tumors from Chernobyl liquidators: comparison with sporadic tumors from Ukrainian and French patients. Endocr Relat Cancer. 2005;12(1):173-83. https://doi. org/10.1677/erc.1.00884 PMID: 15788648

72. Thomas G, Bunnell H, Cook H, Williams E, Nerovnya A, Cherstvoy E, et al. High prevalence of RET/PTC rearrangements in Ukrainian and Belarussian post-Chernobyl thyroid papillary carcinomas: a strong correlation between RET/PTC3 and the solid-follicular variant. J Clin Endocrinol Metab. 1999;84(11):42328. https://doi.org/10.1210/jcem.84.11.6129 PMID: 10566678

73. Goodhead Dt. Initial events in the cellular effects of ionizing radiations: clustered damage in DNA. Int J Radiat Biol. 1994;65(1):7-17. PMID:7905912

74. Caudill CM, Zhu Z, Ciampi R, Stringer JR, Nikiforov YE. Dose-dependent generation of RET/PTC in human thyroid cells after in vitro exposure to $\gamma$-radiation: a model of carcinogenic chromosomal rearrangement induced by ionizing radiation. J Clin Endocrinol Metab. 2005;90(4):2364-9. $\quad$ https://doi.org/10.1210/ jc.2004-1811 PMID: $\underline{15671095}$

75. Leeman-Neill RJ, Brenner AV, Little MP, Bogdanova TI, Hatch M, Zurnadzy LY, et al. RET/ PTC and PAX8/PPAR $\gamma$ chromosomal rearrangements in post-Chernobyl thyroid cancer and their association with iodine-131 radiation dose and other characteristics. Cancer. 2013;119(10):1792-9. https://doi.org/10.1002/ cncr.27893 PMID:23436219

76. Su X, Li Z, He C, Chen W, Fu X, Yang A. Radiation exposure, young age, and female gender are associated with high prevalence of RET/PTC1 and RET/PTC3 in papillary thyroid cancer: a 
meta-analysis. Oncotarget. 2016;7(13):16716.

https://doi.org/10.18632/oncotarget.7574

PMID:26918339

77. Zhang YY, Liu ZB, Ye XG, Ren WM. Iodine regulates $\mathrm{G} 2 / \mathrm{M}$ progression induced by CCL21/CCR7 interaction in primary cultures of papillary thyroid cancer cells with RET/PTC expression. Mol Med Rep. 2016;14(4):3941-

6. https://doi.org/10.3892/mmr.2016.5686 PMID:27574129

Zheng B, Liu J, Gu J, Lu Y, Zhang W, Li M, et al. A three-gene panel that distinguishes benign from malignant thyroid nodules. Int $\mathrm{J}$ Cancer. 2015;136(7):1646-54. https://doi.org/10.1002/ ijc.29172 PMID:25175491

79. Perrone F, Bertolotti A, Montemurro G, Paolini B, Pierotti MA, Colecchia M. Frequent mutation and nuclear localization of $\beta$-catenin in Sertoli cell tumors of the testis. Am J Surg Pathol. 2014;38(1):66-71.

Garcia-Rostan G, Camp RL, Herrero A, Carcangiu ML, Rimm DL, Tallini G. $\beta$-catenin dysregulation in thyroid neoplasms: downregulation, aberrant nuclear expression, and CTNNB1 exon 3 mutations are markers for aggressive tumor phenotypes and poor prognosis.

Am J Surg Pathol. 2001;158(3):987-96. https:// doi.org/10.1016/S0002-9440(10)64045-X PMID:11238046 PMCID:PMC1850336

81. Fagin JA, Matsuo K, Karmakar A, Chen DL, Tang S-h, Koeffler HP. High prevalence of mutations of the p53 gene in poorly differentiated human thyroid carcinomas. J Clin Invest. 1993;91(1):179. https://doi.org/10.1172/

\section{$\underline{\text { JCI116168 }}$ PMID: $\underline{8423216}$}

Donghi R, Longoni A, Pilotti S, Michieli P, Della Porta G, Pierotti MA. Gene p53 mutations are restricted to poorly differentiated and undifferentiated carcinomas of the thy- roid gland. J Clin Invest. 1993;91(4):1753. https://doi.org/10.1172/JCI116385 PMID: $\underline{8473515}$ PMCID:PMC288155

83. Murugan AK, Bojdani E, Xing M. Identification and functional characterization of isocitrate dehydrogenase 1 (IDH1) mutations in thyroid cancer. Biochem Biophys Res Commun. 2010;393(3):555-9. https://doi.org/10.1016/j. bbrc.2010.02.095 PMID:20171178

84. Hemerly JP, Bastos AU, Cerutti JM. Identification of several novel non-p. R132 IDH1 variants in thyroid carcinomas. Eur J Endocrinol. 2010;163(5):747-55. PMID:20702649

85. Omidfar K, Moinfar Z, Sohi AN, Tavangar SM, Haghpanah V, Heshmat R, et al. Expression of EGFRvIII in thyroid carcinoma: immunohistochemical study by camel antibodies. Immunol Invest. 2009;38(2):165-80. https://doi.org/10.108 $\underline{0}$ 088820130902735998

86. Haghpanah V, Shooshtarizadeh P, Heshmat R, Larijani B, Tavangar SM. Immunohistochemical analysis of survivin expression in thyroid follicular adenoma and carcinoma. Appl Immunohistochem Mol Morphol. 2006;14(4):422-5. https://doi.org/10.1097/01.pai.0000213100.88074. b8 PMID: 17122639

87. Tabriz HM, Adabi K, Lashkari A, Heshmat R, Haghpanah V, Larijani B, et al. Immunohistochemical analysis of $\mathrm{nm} 23$ protein expression in thyroid papillary carcinoma and follicular neoplasm. Pathol Res Pract. 2009;205(2):83-

7. https://doi.org/10.1016/j.prp.2008.08.007 PMID: 18996649

88. Haghpanah V, Ghaffari SH, Rahimpour P, Abbasi A, Saeedi M, Pak H, et al. Vitamin D receptor gene polymorphisms in patients with thyroid cancer. Gene Ther Mol Biol B. 2007;11(2):299304.

\section{How to Cite This Article}

Khatami F, Tavangar M. A Review of Driver Genetic Alterations in Thyroid Cancers. Iranian Journal of Pathology, 2018; 13(2): 125-135. 